\title{
RE-SHAPING MALLOTUS [PART 2]: INCLUSION OF NEOTREWIA, OCTOSPERMUM AND TREWIA IN MALLOTUS s.s. (EUPHORBIACEAE s.S.)
}

\author{
K.K.M. KULJU, S.E.C. SIERRA \& P.C. VAN WELZEN \\ Nationaal Herbarium Nederland, Universiteit Leiden branch, \\ P.O. Box 9514, 2300 RA Leiden, The Netherlands; \\ e-mail:kulju@nhn.leidenuniv.nl, sierra@nhn.leidenuniv.nl,welzen@nhn.leidenuniv.nl
}

\begin{abstract}
SUMMARY
A recent molecular phylogenetic study of Mallotus and related genera showed that three small Asiatic genera are clearly part of a strongly supported main Mallotus clade (Mallotus s.s. clade), rendering the genus paraphyletic. In this paper these genera, Neotrewia, Octospermum and Trewia, are merged with Mallotus. The monotypic Neotrewia and Octospermum were originally described within Mallotus and are now transferred back to it. Trewia was never included in Mallotus; it has two distinct species, for which new combinations within Mallotus are made. A full taxonomic treatment with descriptions, distribution maps and drawings is given for the species transferred, and a new generic description for Mallotus is provided. The morphology of the newly transferred species in comparison to Mallotus in general and to related species in particular is discussed.
\end{abstract}

Key words: Rottlerinae, Mallotus, Neotrewia, Octospermum, Trewia, Malesia, taxonomy.

\section{INTRODUCTION}

The large palaeo(sub)tropical genus Mallotus Lour. has been classified in subtribe Rottlerinae with seven or eight small, presumably related, genera (Webster, 1994; Radcliffe-Smith, 2001). Recently, the phylogenetic relationships of these genera, together with another large genus Macaranga Thouars (classified in the separate, monogeneric subtribe Macaranginae by Webster (1994), but morphologically close to Mallotus) were studied using plastid and nuclear sequence data (Kulju et al., in press; see also Slik \& Van Welzen, 2001a). The results clearly show that Mallotus is paraphyletic for two reasons. First, some Mallotus species are placed in a separate clade with the genera Cordemoya Baill. and Deuteromallotus Pax \& K. Hoffm. (the latter was also considered to be congeneric with Mallotus by McPherson, 1995). This Cordemoya s.1. clade is in a basal position in relation to the strongly supported Macaranga and Mallotus s.s. clades. Second, four Rottlerinae genera (Coccoceras Miq., Neotrewia Pax \& K. Hoffm., Octospermum Airy Shaw and Trewia L.) fall into the Mallotus s.s. clade (see Fig. 2 and 5 in Kulju et al., in press).

The paraphyly caused by the Cordemoya s.l. clade has been dealt with in a separate article by extending Cordemoya to include the genus Deuteromallotus, and Mallotus sections Diplochlamys (Müll.Arg.) Baill. (= Hancea Seem.) and Oliganthae Airy Shaw (Sierra et al., 2006). Based on the morphology, the genus Coccoceras was 
already merged with Mallotus (Airy Shaw, 1963; Bollendorff et al., 2000). In this paper Neotrewia, Octospermum and Trewia, three Asiatic mono- or ditypic genera largely resembling Mallotus, are merged with it and a new circumscription of Mallotus s.s. is provided. The morphology of the four transferred species is discussed in comparison to Mallotus and a taxonomic treatment of them is given with morphological descriptions, distribution maps and drawings.

\section{MORPHOLOGICAL COMPARISONS}

Mallotus and the species previously assigned to Neotrewia, Octospermum and Trewia have a very similar general appearance. In particular, they share the pollen type (perforate/microreticulate ornamentation with scabrae) and the extrafloral nectaries on the upper leaf surface. Furthermore, all these taxa possess a similar type of glandular hairs ${ }^{1}$, a character typical for most Mallotus and Macaranga species and rare outside subtribe Rottlerinae (Macaranga is a sister clade of the Mallotus s.s. clade; see Kulju et al., in press). The morphological similarity of Neotrewia and Octospermum with Mallotus is additionally demonstrated by the fact that they are solely based on species originally described within Mallotus. Also, at least in the cases of Octospermum and Trewia, Mallotus species or species groups clearly similar to them can be found (see below); this bridges further the gap between the genera.

In fact, the only characters distinguishing Neotrewia, Octospermum and Trewia from Mallotus are the number of locules in the ovary and the fruit type. The locule number in these genera can vary from one to nine (2- or 3-locular ovaries are typical for Mallotus) and the fruits are indehiscent ${ }^{2}$ (generally dehiscent in Mallotus). These differences, especially the fruit dehiscence, are of course distinct and easily notable, but they form a weak justification for a separate generic status, because the variation in these characters within Mallotus is larger than generally acknowledged. Firstly, some Mallotus species can have up to five locules per ovule (Sierra \& Van Welzen, 2005; Sierra et al., 2005). Secondly, indehiscent fruits are present in several Mallotus species (e.g., M. blumeanus Müll.Arg., M. chromocarpus Airy Shaw and M. sphaerocarpus Müll. Arg.; also several species formerly assigned to the genus Coccoceras have indehiscent or tardily dehiscent fruits; Bollendorff et al., 2000). The development of indehiscent, often fleshy, fruits from typical explosively dehiscent euphorb capsules seems to have independently happened in several Euphorbiaceae groups (Haegens, 2000; Esser, 2003; Wurdack et al., 2005), leading to paraphyletic taxa if this transformation is given too much weight, as demonstrated in this case.

\section{Neotrewia}

The monotypic Malesian genus Neotrewia was described by Pax \& Hoffmann (1914), based on Mallotus cumingii Müll.Arg., a name which is adopted here again. The same species was also described as Trewia ambigua by Merrill (1906). The fruits

1) The glandular scales of Neotrewia and Trewia are often very few and difficult to spot and are often not reported in generic descriptions (e.g., Radcliffe-Smith, 2001).

2) With the exception of the poorly known species Trewia polycarpa Benth. \& Hook.f., which has 2-locular ovaries and dehiscent fruits (see below). 
of this species are unilocular (or rarely bilocular) and indehiscent. The pericarp wall is apparently not fleshy. The opposite leaf arrangement suggests affinity with the species-rich section Rottleropsis of Mallotus (see the revision by Sierra et al., 2007); this is confirmed by the phylogenetic study (Kulju et al., in press).

\section{Octospermum}

Pax \& Hoffmann (1914) described Mallotus pleiogynus, a new species of Mallotus from New Guinea and placed it in the new and monotypic section Pleiogyni. Because of its peculiar pistillate characters, Airy Shaw (1965) transferred it to the new genus Octospermum. This species has 7-9-locular ovaries and toughly fleshy, indehiscent fruits with longitudinal ridges. It is also an exceptionally tall tree (up to $43 \mathrm{~m}$ ) as compared to other Mallotus species.

However, M. pleiogynus has similarities with three other Mallotus species from New Guinea and Australia (M.chromocarpus Airy Shaw, M. discolor F. Muell. ex Benth. and M. nesophilus Müll.Arg.): stipules absent, anther connectives conspicuously broadened (umbrella-like) and fruits indehiscent. In the phylogenetic study M.pleiogynus groups with $M$. discolor (the other two species were not sampled). A tentative sister species to M. pleiogynus is M. chromocarpus, another New Guinean endemic (the two other species in this group are Australian), as they differ primarily by the number of locules (3-5 in M.chromocarpus; Sierra et al., 2005). All of these four species have alternate leaves and unarmed fruits, a combination typical for Mallotus sect. Philippinenses. However, Sierra et al. (2005) excluded M. chromocarpus from this section based on the special characters mentioned above (the same applies to M.discolor and M. nesophilus). Due to poor support in the phylogenetic tree (Kulju et al., in press), this could not be verified, although sect. Philippinenses, with or without the four species mentioned here, does not seem to form a monophyletic group.

\section{Trewia}

Trewia was established by Linnaeus (1753) based on the single species T. nudiflora. The description of this species is solely based on the figure of 'Canschi' in Van Rheede's Hortus Malabaricus (1678). Willdenow (1797) described the same plant as Rottlera indica, but later synonymised it with T. nudiflora (1806). He (1797) also treated Tetragastris ossea Gaertn., the type species of Tetragastris Gaertn., as a synonym of $R$. indica. This makes the name Rottlera indica superfluous and, actually, a synonym of the genus Tetragastris in the Burseraceae (Tetragastris ossea has been shown to belong to the Burseraceae and be related to the genus Protium; see Swart, 1942).

Several Trewia species were described after Linnaeus, but most of these proved either to be conspecific with T. nudiflora or to belong to other Euphorbiaceae genera. Only the status of the Indian T. polycarpa Benth. raises serious taxonomic questions (see below).

In the phylogenetic tree (Kulju et al., in press) T. nudiflora forms a highly supported clade with Mallotus khasianus Hook.f. (sect. Rottleropsis; Sierra et al., 2007); both have an often deciduous habit and similar, long staminate inflorescences. As this clade is positioned as sister to the rest of Mallotus s.s., Mallotus could be made monophyletic by transferring M. khasianus to Trewia. However, we opt for an alternative solution, which is to merge T.nudiflora with Mallotus, for two reasons. First, the sister group relationship of the T. nudiflora-M. khasianus clade and the rest of Mallotus 
s.s. is not well supported (also, the preliminary analyses with different markers and more extensive taxon sampling place this clade nested inside Mallotus s.s.). Second, M. khasianus has typical dry, dehiscent Mallotus capsules, and merging it to Trewia would leave both genera without a distinguishing set of morphological characters. Therefore, a new combination for T. nudiflora, Mallotus nudiflorus (L.) Kulju \& Welzen, is made here.

Trewia, a Linnaean name, is older than the name Mallotus and, therefore, all Mallotus species should be transferred to Trewia. However, this would cause a great nomenclatural instability, requiring new combinations for more than a hundred Mallotus species. Mallotus is far more widely known than Trewia, not only because of the many species, but also because it has a much wider distribution, ranging from Africa to the West Pacific. Furthermore, Mallotus is not only a name familiar among systematists, it is an ecologically important genus too; Mallotus species are, for instance, important as ecological indicators (Slik et al., 2003; Slik, 2005). As a transition of Mallotus to Trewia is thus unwanted, we have submitted a proposal to conserve the genus Mallotus against Trewia (Kulju \& Van Welzen, submitted), and in the present paper the name Mallotus is used for the genus.

\section{The intraspecific variation of Mallotus nudiflorus}

Mallotus nudiflorus, having a relatively wide distribution range from India to West Malesia, shows considerable variation in the type and density of the indumentum, the number of fruits per pistillate inflorescence and the size of the fruit. The indumentum varies from dense with long hairs to subglabrous with short hairs. This variation is seemingly uncorrelated with geography, because the different forms occur within most areas (Table 1). Variation in the fruit size is mainly caused by the thickness of the pericarp and is loosely correlated with the number of fruits per infructescence (1- or 2 -fruited infructescences tend to have bigger fruits than many-fruited ones). Overall, $M$. nudiflorus is most diverse in India.

\section{The status of Trewia polycarpa}

Bentham \& Hooker (1880) distinguished the Indian species T. polycarpa from T. nudiflora by several pistillate characters, and various Indian floras have followed

Table 1. Indumentum and fruit variation in Mallotus nudiflorus. $\mathrm{n} / \mathrm{a}$ : information not available.

\begin{tabular}{llll}
\hline & Indumentum & $\begin{array}{l}\text { Fruits per } \\
\text { infructescence }\end{array}$ & Fruit size \\
\hline India & nearly absent to dense & $1-5$ & small to large \\
Ceylon & nearly absent & $1-5$ & small \\
Nepal, Bhutan, Burma, China & sparse to dense & mostly 1 & medium to large \\
Thailand, Indo-China & sparse to dense & 1 & large \\
Peninsular Malaysia & sparse to dense & n/a & n/a \\
Sumatra, Borneo & nearly absent to sparse & 1 or 2 & medium \\
Java & sparse to dense & $2-4$ & medium \\
Philippines & nearly absent to dense & $1-4$ & n/a \\
\hline
\end{tabular}


their treatment. In contrast, Pax \& Hoffmann (1914) treated T. polycarpa as a synonym of T. nudiflora and, recently, Susila Rani \& Balakrishnan (1998) treated it as a variety of T.nudiflora, differing only by "smaller fruits with thinner pericarp". Here this taxon is treated as a distinct species within Mallotus, for which the new combination $M$. polycarpus (Benth.) Kulju \& Welzen is made.

After studying the Indian material previously known as Trewia, including the type of $T$. polycarpa, we conclude that $M$. polycarpus is indeed a separate species from $M$. nudiflorus because of the strong differences in inflorescence and fruit (compare Fig. 2 and 4). Mallotus nudiflorus has 1-5-flowered pistillate inflorescences with flowers only in the apical part, 3-5-locular ovaries and indehiscent, oblate fruits; whereas M. polycarpus has 6-17-flowered pistillate inflorescences with flowers also in the basal part, 2-locular ovaries and loculicidally dehiscent, ovoid to ellipsoid fruits.

The above-mentioned differences are consistent with the original diagnosis of T. polycarpa, in which, however, Bentham \& Hooker (1880) also referred to two previously published figures of pistillate specimens as T.polycarpa. These figures (Wight, 1852: t. 1871; Beddome, 1872: t. 281) have a 3- or 4-locular ovary and M.nudifloruslike inflorescences and, therefore, clearly represent $M$. nudiflorus as delimited here. The presence of these two conflicting elements in Bentham \& Hooker (1880), the diagnosis (matching the type) and the figure references (resembling $M$. nudiflora), was probably the original source of the confusion concerning the status of these two taxa in many Indian floras and the tendency to treat the two species as synonyms.

Indian Trewia material studied here (c. 90 specimens) contained only two true M. polycarpus specimens with 2-locular, dehiscent fruits (although several collections of $M$. nudiflorus were misidentified as it). A search through Indian Mallotus material at $\mathrm{L}$ and $\mathrm{K}$ did not reveal additional $M$. polycarpus specimens either. Apparently, this species is very rare.

Because DNA extractions from $M$. polycarpus were not successful, it was not included in the phylogenetic study (Kulju et al., in press). Although a plant with globose to discoid glandular hairs, extrafloral nectaries on the upper leaf surface and 2-locular ovaries could be placed in the genus Macaranga as well, the presence of opposite leaves, unequal in size, clearly point to Mallotus s.s. However, because of the strikingly different inflorescence and fruit and the scarcity of material, especially the absence of staminate specimens, it is unclear if this species could be the sister species of M.nudiflorus or if it is more closely related to other Mallotus species.

\section{TAXONOMIC TREATMENT OF THE TRANSFERRED SPECIES}

\section{MALLOTUS s.s. - Map 1}

Mallotus Lour., Fl. Cochinch. (1790) 635, nom. cons. propos.

Trewia ('Trevia', see notes 1 and 2) L. (1753) 1193; Burm.f. (1768) 298 ('Trevia'); Neck. (1790) 268; Willd. (1806) 834; Sm. (1819) 7; Blume (1826) 612; Endl. (1843) 98; Baill. (1858) 408; Miq. (1859) 399; Müll.Arg. (1866) 953; Bedd. (1872) 281; Kurz (1877) 378; Benth. in Benth. \& Hook.f. (1880) 318; Hook.f. (1887) 423; Pax (1896) 53; Brandis (1906) 590; T. Cooke (1906) 613; J.J. Sm. (1910) 389; Talbot (1911) 481; Pax \& K. Hoffm. (1914) 140; Gamble (1925) 1318; Backer \& Bakh.f. (1964) 481 ('Trevia'); Airy Shaw (1972) 343; Whitmore (1973) 134; Airy Shaw 
(1975) 200; (1981) 350; (1983) 46; Grierson \& D.G. Long (1987) 798; H.S. Kiu et al. (1996) 11; Philcox (1997) 142; Susila \& N.P. Balakr. (1998) 345; Govaerts et al. (2000) 1560. - Canschi Adans. (1763) 443, nom. superfl. - Type species: Trewia nudiflora L., syn. nov.

Neotrewia Pax \& K. Hoffm. (1914) 211; Merr. (1923) 437; Pax \& K. Hoffm. (1931) 118; Airy Shaw (1982) 31; (1983) 39; G.L. Webster (1994) 90; Govaerts et al. (2000) 1217; Radcl.-Sm. (2001) 232. - Type species: Neotrewia cumingii (Müll.Arg.) Pax \& K. Hoffm., syn. nov.

Octospermum Airy Shaw (1965) 311; (1980) 176; G.L. Webster (1994) 90; Govaerts et al. (2000)

1219; Radcl.-Sm. (2001) 232. - Type species: Octospermum pleiogynum (Pax \& K. Hoffm.)

Airy Shaw, syn. nov.

Rottlera auct. non Willd.: Willd. (1797) 7, quoad. descr. (non 1806).

For a more extensive list of synonyms see Bollendorff et al., 2000; Slik \& Van Welzen, 2001b;

Sierra \& Van Welzen, 2005; Sierra et al., 2005; Sierra et al., 2007.

Shrubs, trees, to rarely climbers, dioecious (or monoecious), evergreen or sometimes deciduous. Indumentum consisting of simple, tufted, stellately-tufted, or stellate, or rarely peltate hairs; glandular hairs globular to disc-shaped, usually conspicuous, rarely absent. Stipules axillary, rarely absent. Leaves alternate to opposite, usually unequal in size when opposite, simple, sometimes lobed; blade entire to crenate to dentate, often with minute glandular teeth, base sometimes peltate; upper surface almost always with elliptic or orbicular, usually conspicuous, extrafloral nectaries, which are basally and/or marginally distributed (or along midrib or all over the lamina), glandular hairs present or absent; lower surface usually with glandular hairs, domatia sometimes present; venation pinnate, triplinerved or palminerved, nerves looping or ending in the margin, veins scalariform, veinlets reticulate. Inflorescences axillary or terminal, rarely ramiflorous or cauliflorous, spikes, racemes, panicles, glomerules or umbel-like, or reduced to one flower, unisexual, rarely bisexual; bracts 1 (several when umbel-like) per node, margin entire, rarely trilobed, bracteoles sometimes present; staminate flowers 1-15 (to rarely more) per bract, pistillate flowers one per bract (to several when umbel-like). Flowers: flowers not exceeding $10 \mathrm{~mm}$ diam., usually pedicellate, pedicels sometimes with abscission zone; sepals valvate, free or connate, usually persistent; petals absent. Staminate flowers: sepals ( 2 or) 3-5; interstaminal disc-glands sometimes present; stamens 15-130, filaments free or connate, anthers basifixed, thecae 2, longitudinally dehiscent, connective narrow to distinctly broadened, sometimes irregularly apiculate, papillose; pollen 3- (rarely 4-)colporate, ornamentation perforate/microreticulate with scabrae; pistillode sometimes present. Pistillate flowers: sepals (2 or) 3-6; disc absent; ovary (1- or) 2- or 3- (to rarely 9-)locular, 1 ovule per locule; style present or absent; stigmas simple, (erect to) reflexed, (papillose or) plumose. Fruits dehiscent to tardily dehiscent capsules, or indehiscent, drupaceous and variously fleshy, usually lobed (to globose), rarely with wings or longitudinal ridges, surface smooth to spiny (to somewhat rugose to verrucose), hairy (to glabrous), sometimes with glandular hairs, opening septicidallyloculicidally to loculicidally-septicidally, or rarely only loculicidally; column usually present. Seeds $( \pm)$ globose, rarely triangular in cross section or lenticular, sometimes with a thin sarcotesta, surface smooth to rugose, caruncle absent.

Distribution - From West (Senegal to Liberia) to East (Ethiopia to Tanzania) Africa to West Madagascar, Pakistan, Sri Lanka, India, Bangladesh, Myanmar and Nepal, South China, Korea, South Japan, throughout Southeast Asia and Malesia to East Australia and the West Pacific (Solomon Islands, Palau, Federated States of Micronesia, New Caledonia, Fiji). 


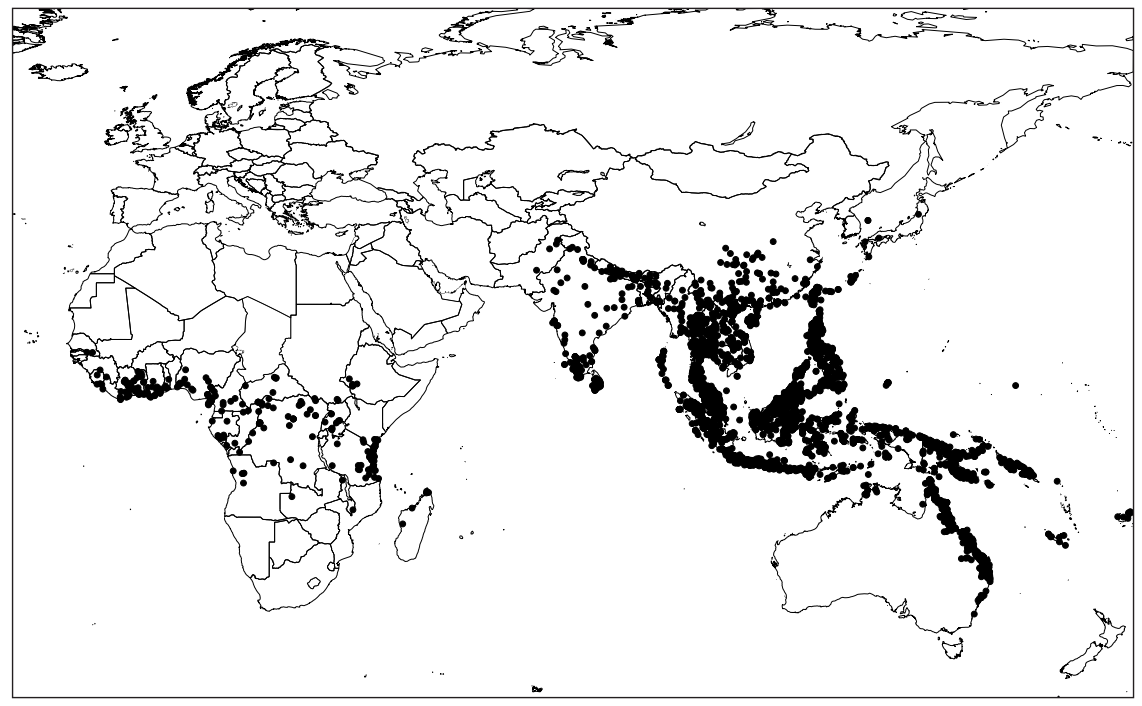

Map 1. Approximate distribution of the genus Mallotus s.s.

Notes - 1. Trewia L. is the oldest name for the genus, as circumscribed here. However, we have submitted a proposal to conserve Mallotus against Trewia to maintain nomenclatural stability (see text).

2. Originally Linnaeus (1753) spelled the genus name as 'Trevia', but later he inconsistently used both 'Trevia' and 'Trewia' (see Nicolson et al., 1988). Since Linnaeus, almost all authors have adopted the spelling 'Trewia'. The present code (McNeill et al., 2006: art. 13.4) gives priority to the original spelling given in Species Plantarum (1753) and therefore 'Trevia' should be used. However, since this genus is here present only in the synonymy of Mallotus, we have continued to follow the widely used spelling 'Trewia'.

\section{Mallotus cumingii Müll.Arg. - Fig. 1; Map 2}

Mallotus cumingii Müll.Arg. (1865) 195; (1866) 978; S. Vidal (1886) 245. - Neotrewia cumingii (Müll.Arg.) Pax \& K. Hoffm. (1914) 212; Merr. (1923) 437; Airy Shaw (1982) 31; (1983) 39; De Guzman et al. (1986) 292. - Type: Cuming 798 (holo G-DC, microfiche seen, IDC \#800; iso BM, CGE, K, L, W), Philippines, Luzon, Tayabas Province.

Trewia ambigua Merr. (1906) 79. - Syntypes: FB 623 (Borden) (BM, K, US), Philippines, Luzon, Bataan Province, Lamao River; FB 1251 (Borden) (BM, K, US), Philippines, Luzon, Bataan Province, Lamao River, Mt Mariveles; FB 2798 (R. Meyer) (K, NY, US), Philippines, Luzon, Bataan Province, Lamao River, Mt Mariveles.

Shrubs to small trees up to $18(-25) \mathrm{m}$ high, dbh up to $30(-45) \mathrm{cm}$, dioecious, evergreen; young branches usually flattened when dry, sparsely to densely hairy, older ones terete, glabrescent; flowering branches 1-5 mm thick. Outer bark smooth to rugose, often peeling in thin plates, grey to (yellowish or reddish) brown, sometimes patchy. Indumentum with simple to (stellately) tufted hairs, whitish to yellowish (to brownish); glandular hairs yellowish to reddish, in most parts absent (to sparsely present). Stipules 


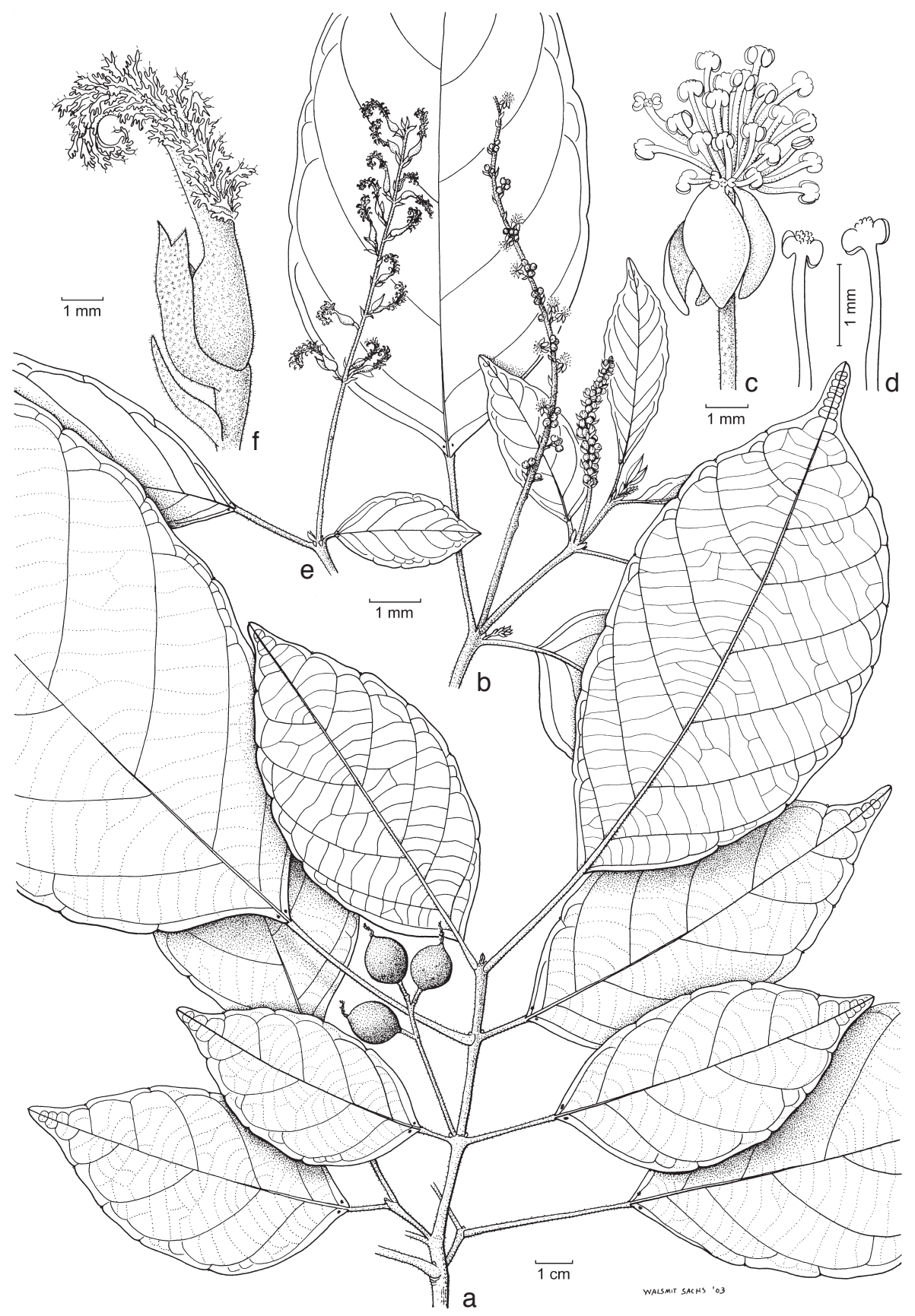

Fig. 1. Mallotus cumingii Müll.Arg. a. Habit of pistillate plant with fruits; b. staminate plant with inflorescences; c. staminate flower; d. stamens; e. pistillate inflorescence; f. pistillate flower with a bract (a: Soejarto, Madulid \& Fernando 7786, L; b-d: PNH 22901, L; e, f: Wenzel 211, NSW). 
(narrowly) triangular to obovate, $1.8-6$ by $0.7-2 \mathrm{~mm}$, early caducous, margin entire, apex obtuse to acute, densely hairy outside, sparsely (to densely) hairy inside. Leaves opposite; petiole $0.4-11.8 \mathrm{~cm}$ long, with or without a basal and apical pulvinus, glabrous to densely hairy; blade ovate to obovate, $4.8-35.5$ by $1.5-19.5 \mathrm{~cm}$, length/width ratio $1.3-3.5$, papery, base (truncate to) obtuse to cuneate to attenuate, margin subentire to wavy (to subdentate), glandular teeth $2-12(-16)$ per side, often puberulus or papillose and located in a minute notch, apex (rounded to) acuminate to cuspidate, usually ending in a gland; upper and lower surface glabrous, to sparsely hairy on the venation; upper surface dark green, somewhat shiny, smooth to sparsely granular dotted, basal extrafloral nectaries 2-4(-8), 0.5-18 $\mathrm{mm}$ from petiole insertion, marginal extrafloral nectaries 0-5(-12) per side, 1.6-15 mm from margin; lower surface paler green, densely dotted with minute bumps, glandular hairs sometimes present in young leaves, caducous to sparsely present in adult leaves, hair-tuft domatia sometimes present; venation pinnate, nerves 4-11 per side, looped and closed near the margin. Inflorescences axillary racemes, single, or rarely 2 together when staminate, axis sparsely to densely hairy; bracts mostly caducous, ovate to triangular, somewhat cymbiform, margin entire, apex (obtuse to) acute to acuminate, both sides hairy to subglabrous inside when pistillate. Flowers: pedicels sparsely to densely hairy, with basal abscission zone; sepals sparsely hairy outside, (sub) glabrous inside. Staminate inflorescences up to $21 \mathrm{~cm}$ long, basally $0.6-1.5 \mathrm{~mm}$ thick; bracts $1.2-2.5(-3.7)$ by $0.6-1.3 \mathrm{~mm}$. Staminate flowers: buds globose, apiculate or not; flowers 3.2-5.2(-6.9) mm diam., white to cream to yellowish, with sweet odour; pedicels 1.8-5.2(-6.8) mm long; sepals ( 2 or) 3 or 4, free (to basally connate), ovate to elliptic, $1.8-3.2$ by $0.8-1.9 \mathrm{~mm}$, often recurved when dry, apex obtuse to acuminate, sometimes with glandular hairs outside; disc-glands often present; stamens 30-60, filaments $0.9-3.1(-4.2) \mathrm{mm}$ long, free, glabrous, thecae $0.2-0.5$ by 0.15-0.25 mm, opposite to subalternate, opening latrorsely to irregulary, connective up to twice as wide as the filament, papillose, apex irregulary apiculate or widened. Pistillate inflorescences up to $12.5(-19) \mathrm{cm}$ long, basally $0.7-2.5 \mathrm{~mm}$ thick; bracts 1.1-2.6 by $0.5-0.9 \mathrm{~mm}$. Pistillate flowers: buds ovoid, 0.7-1.1 mm diam. just before anthesis; flowers greenish, with a faint, sweet odour; pedicels 0.9-7.4 mm long; calyx 2.9-4.5 mm long, opening via 1 or 2 sutures, soon caducous; ovary ellipsoid, densely hairy, glandular hairs usually present, locules 1 (or 2); style $0.5-3(-4) \mathrm{mm}$ long, sparsely to densely hairy, smooth to verrucose; stigma 4.4-8.4 mm long, reflexed, stigmatic side plumose, non-stigmatic side hairy. Fruits indehiscent, dry drupes, (oblate to) spheroid to broadly ellipsoid, often slightly bilobed when 2 -seeded, $9-15$ by $9-15 \mathrm{~mm}$, often with style remnants, surface smooth to slightly verrucose, hairy, with or without some glandular hairs, speckled, (yellowish) green to (reddish) brown when fresh, brown to dark grey when dry; pericarp 0.4-2.9 mm thick, dry, hard to somewhat brittle. Seeds oblate to spheroid to broadly ellipsoid, $6-10$ by $7-12 \mathrm{~mm}$, surface smooth, white to brown, sarcotesta absent.

Distribution - Borneo, Philippines, Sulawesi.

Habitat \& Ecology - In primary and secondary forest, frequently in damp places along rivers and streams. Altitude up to $1000(-1660) \mathrm{m}$. Flowering and fruiting (in Philippines): throughout the year, flowering especially from March to June.

Vernacular names - Philippines: Banilad, bunog (Tagbanua); batobato (Tagalog); wamut (Subanun); apanang, balogo, cabantala, potian, suysuysagpub, tabunghain. 


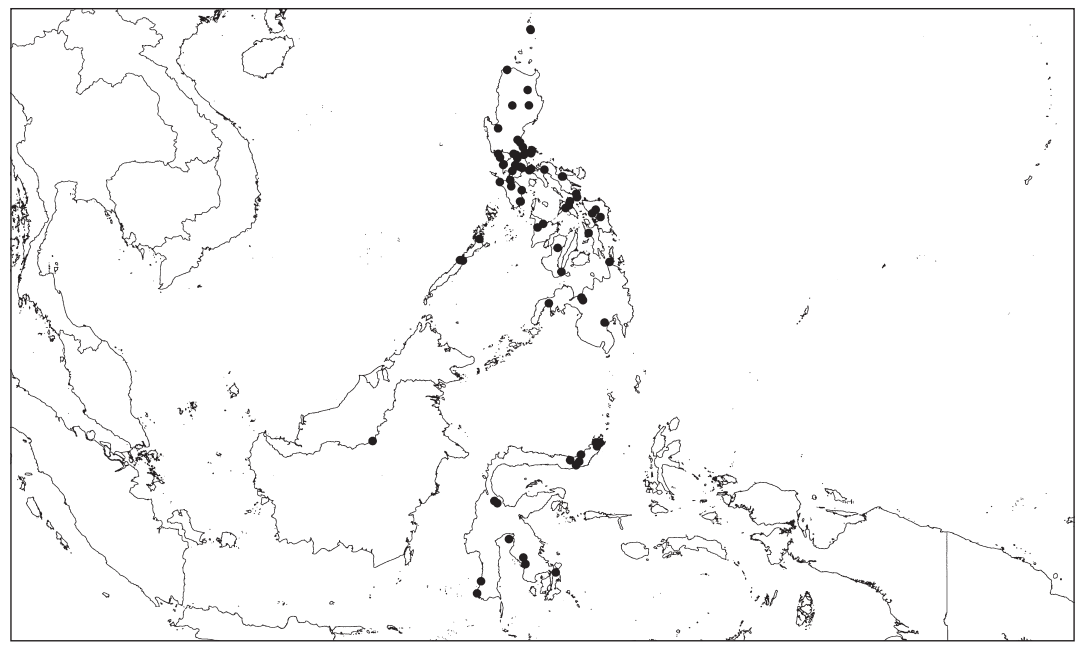

Map 2. Distribution of Mallotus cumingii Müll.Arg.

Notes -1 . This species shows a large variation in leaf size, which is partly caused by the size inequality of each leaf pair. The variation is, however, continuous and does not correlate with other characters. Specimens from Batan Island, Philippines (BS $80605, B S 80686, B S 80720$ ) differ from others by having only ovate leaves with low length/width ratios and somewhat longer staminate bracts.

2. The distribution of this species, previously only know from the Philippines and Sulawesi, is here extended to Borneo. Only one Bornean specimen, S series 28705 (Kapit Distr., Sarawak), is known so far.

3. Five specimens from the Lesser Sunda Islands (Kostermans 18263, Kostermans 18736, Mulyati et al.503, Schmutz 4133, Schmutz 4797) resemble M. cumingii closely, but differ from it by the consistent presence of glandular hairs on the lower leaf surface, and short and stout staminate inflorescences covered with hairs longer than in $M$. cumingii. As pistillate specimens are not known, the status of these collections remains unclear.

\section{Mallotus nudiflorus (L.) Kulju \& Welzen, comb. nov. - Fig. 2; Map 3}

Trewia ('Trevia') nudiflora L., Sp. Pl. (1753) 1193; Willd. (1806) 834; Sm. (1819) 8; Wight (1852) 21, t. 1870, 1871; Baill. (1858) 409; Miq. (1859) 400; Müll.Arg. (1866) 953; Bedd. (1872) 281; Kurz (1877) 379; Benth. in Benth. \& Hook.f. (1880) 318; Hook.f. (1887) 423; Pax (1896) 53; Brandis (1906) 590; T. Cooke (1906) 614; J.J. Sm. (1910) 390; Craib (1911) 466; Talbot (1911) 481; Pax \& K. Hoffm. (1914) 140; Troup (1921) 841; Merr. (1923) 431; Gamble (1925) 1319; Gagnep. \& Beille (1925) 343; Backer \& Bakh.f. (1964) 481 ('Trevia'); Airy Shaw (1966) 405; (1969) 79; (1972) 343; Whitmore (1973) 134; Airy Shaw (1975) 200; (1981) 350; (1983) 46; Grierson \& D.G. Long (1987) 799; Nicolson et al. (1988) 119; H.S. Kiu et al. (1996) 11; Vu Van Dung (1996) 249; Philcox (1997) 143; Susila \& N.P. Balakr. (1998) 345, p.p.; S. Gardner et al. (2000) 322; Govaerts et al. (2000) 1560. - Trewia integerrima Stokes (1812) 570 ('Treuia'), nom. superfl. - Trewia nudiflora var. nudiflora: Susila \& N.P. Balakr. (1998) 347, t. 1. - Type: Rheede, Hort. Malab. 1: 76, t. 42 ('Canschi') 1678. 
Trewia macrophylla Roth (1821) 373 (non Blume, 1825). - Type: Heyne s.n. (B †), India orientalis. Trewia macrostachya Klotzsch in Klotzsch \& Garcke (1862) 117, t. 23. - Type: Hoffmeister s.n. (n.v., B†?), Himalaya.

Mallotus cardiophyllus Merr. (1912) 398. - Type: Cuming 1267 (iso A, BM, CGE, K, L, W), Philippines, Luzon, Cagayan Province.

Trewia nudiflora L. var. tomentosa Susila \& N.P. Balakr. (1998) 351, t. 3. - Type: G.V. Subba Rao 62480A/B (holo MH n.v.; iso MH n.v.), India, Andra Pradesh, Srikakulam Distr., near Regadi.

Rottlera indica auct. non Willd.: Willd.(1797) 8, quoad. descr., voucher Klein s.n. (B-Willd, microfiche seen, IDC \#7440 index nr. 18504), India orientalis.

(Large shrubs to) trees up to $30 \mathrm{~m}$ high, dbh up to $50(-80) \mathrm{cm}$, dioecious, deciduous, flowering before or at the time of leaf appearance; branches ribbed when dry, young ones glabrous to hairy, sometimes with glandular hairs, older ones glabrescent; flowering branches $1.6-8.5 \mathrm{~mm}$ thick. Outer bark thin, smooth (to slightly rough), grey to brown (to tan), sometimes patchy. Indumentum with simple to tufted hairs, short to long and soft, whitish to yellowish to brownish, density in most parts varying greatly; glandular hairs yellowish, often (almost) absent. Stipules (narrowly) triangular, $1.8-5.2$ by $0.5-1.5 \mathrm{~mm}$, early caducous, margin entire, apex acute, (subglabrous to) hairy outside, (sub)glabrous inside. Leaves opposite to subopposite; petiole 1.8-12 $\mathrm{cm}$ long, often with a basal constriction when dry, glabrous to hairy, sometimes with glandular hairs; blade ovate, $6-21$ by $6.3-16.5 \mathrm{~cm}$, length/width ratio $1-2.3(-4.8 \mathrm{in}$ immature leaves), papery, base cordate to obtuse (to acute to cuneate especially in immature leaves), not peltate to subpeltate, very base often attenuate, margin subentire (to rarely basally serrate with 1-7 minute teeth per side), apex (acute to) acuminate; upper surface glabrous to sparsely hairy (to densely hairy at venation), dark green, usually granular dotted, basal extrafloral nectaries 2-5, 1-16 mm from petiole insertion, marginal extrafloral nectaries $0-8(-20)$ per side, 3-26 mm from margin; lower surface glabrous to densely hairy, lighter green, glandular hairs absent to sparse, hairtuft domatia sometimes present; venation triplinerved (to 5-nerved), nerves 3-7 per side, looped and closed near the margin. Inflorescences axillary racemes, pendulous when staminate, single, or often 2 or 3 together when staminate, axis subglabrous to hairy; staminate flowers many, ( 2 or) 3 (or 4 ) per node, pistillate flowers $1-5$ at apical part, single per node; bracts early caducous to somewhat persistent when staminate, triangular, staminate ones cymbiform to recurved, margin entire to ciliate, apex acute, hairy to apically glabrous outside, (sub)glabrous inside. Staminate inflorescences up to $30 \mathrm{~cm}$ long, basally $0.6-2.1 \mathrm{~mm}$ thick; bracts $1.5-3.9$ by $0.8-1.7 \mathrm{~mm}$. Staminate flowers: buds ovoid to ellipsoid, hairy-apiculate; flowers 4.7-9 mm diam.; pedicels 3.9-10 mm long, hairy, with widened and more hairy abscission zone at basal part; sepals ( 2 or) 3 or 4 , free, (ovate to) elliptic, (3.2-)3.7-6 by (1.8-)2.1-3.7 mm, often recurved, apex acute to acuminate, subglabrous to hairy outside, sometimes with scattered glandular hairs, (sub)glabrous inside, light yellowish to light greenish; receptacle slightly swollen; disc-glands absent; stamens (25-)45-75(-130), filaments 1.1-6 mm long, free, glabrous, whitish to light greenish, thecae $0.8-1.7$ by $0.3-0.6$ by $0.2-0.4$ $\mathrm{mm}$, opposite to subalternate, opening extrorsely to latrorsely, light yellowish to light greenish, connective widened or not. Pistillate inflorescences $1.5-10.5 \mathrm{~cm}$ long; bracts $1.2-3.2$ by $0.5-2.1 \mathrm{~mm}$. Pistillate flowers: pedicel $1.1-9 \mathrm{~mm}$ long, usually more hairy than inflorescence axis; calyx 4.7-6.4 mm long, connate with 3-5 lobes, opening further with 1 or 2 sutures, soon caducous, hairy outside, (sub)glabrous to 


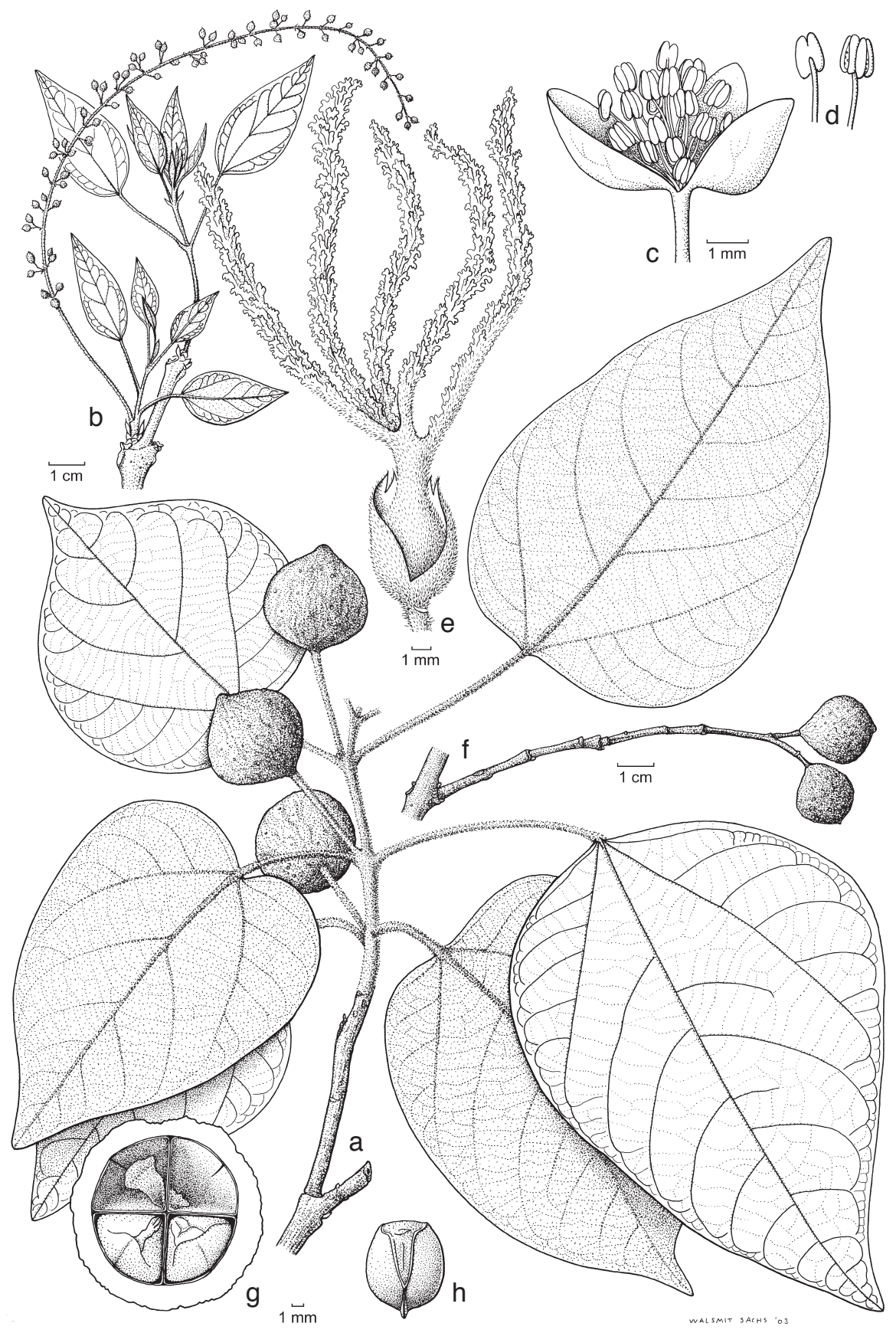

Fig. 2. Mallotus nudiflorus (L.) Kulju \& Welzen. a. Habit of pistillate plant with fruits; b. staminate inflorescence with young leaves; c. staminate flower; d. stamens; e. pistillate flower; f. branch with leaf scars and a 2-fruited infructescence; g. cross section of fruit; h. seed (a: Maxwell 96-956; b: Maxwell 95-9; c, d: Geesink \& Maxwell 7811; e: Maxwell 95-7; f-h: Kostermans 6986; all L). 
sparsely hairy inside; ovary ovoid to ellipsoid, densely shortly hairy, glandular hairs present to absent, locules 3-5; style (1.7-)2.4-4.5(-5.9) mm long, hairy, glandular hairs (present to) absent; stigmas 12-24 mm long, plumose inside, hairy outside. Fruits indehiscent, drupaceous, oblate (to spheroid), $18-29$ by $21-35 \mathrm{~mm}$ when dry, up to 35 by $45 \mathrm{~mm}$ when fresh, surface rugose when dry, subglabrous to hairy, light green to light brown to greyish, speckled; pericarp 2-8 mm thick when dry, mesocarp somewhat hard and fleshy, endocarp crustaceous. Seeds in cross section somewhat triangular to almost elliptic, $8-12$ by $7-10$ by $6-8 \mathrm{~mm}$, surface smooth, brown to black, with thin sarcotesta.

Distribution - From India and Nepal throughout mainland Southeast Asia to southern China (Hainan, Yunnan) and West Malesia (Malay Peninsula, Sumatra, Borneo, Java, Philippines).

Habitat \& Ecology - Deciduous to evergreen forest, usually disturbed and (partly) open sites, usually near streams and rivers, often on alluvial, but also on dry ground; bedrock varying (granite to limestone to shale to quartzite). In lowland Nepal M.nudiflorus is a common tree in riverine forests and dispersed by rhinoceros and domestic cattle (Dinerstein \& Wemmer, 1988). Altitude up to $1200 \mathrm{~m}$. Flowering in mainland Asia: mainly from December to April; fruiting: May to September.

Vernacular names - Nepal: Ramrita, belar (Nepali). India: Bhillaur, bhillaura, katkumbla, khamara, pitali, petari, pindára, tumri. Sri Lanka: Opina (Sinhala); tidimbi (Tamil). Burma: Bolon, set kadon. China: Foo pei shu, ma sze tsz, wak to shue. Laos: Gohk bawp. Thailand: Ma fo, ma po. Java: Binung putjang, gemblok. Borneo: Pridja buaja. Partly after Watt (1893), Brandis (1906), Smith (1910) and Pax \& Hoffmann (1914).

Uses - Wood is used for implements; leaves for fodder (Nepal). Medicinal uses: to remove swelling and bile, to relieve flatulence, for gout and rheumatic afflictions (India, Nepal).

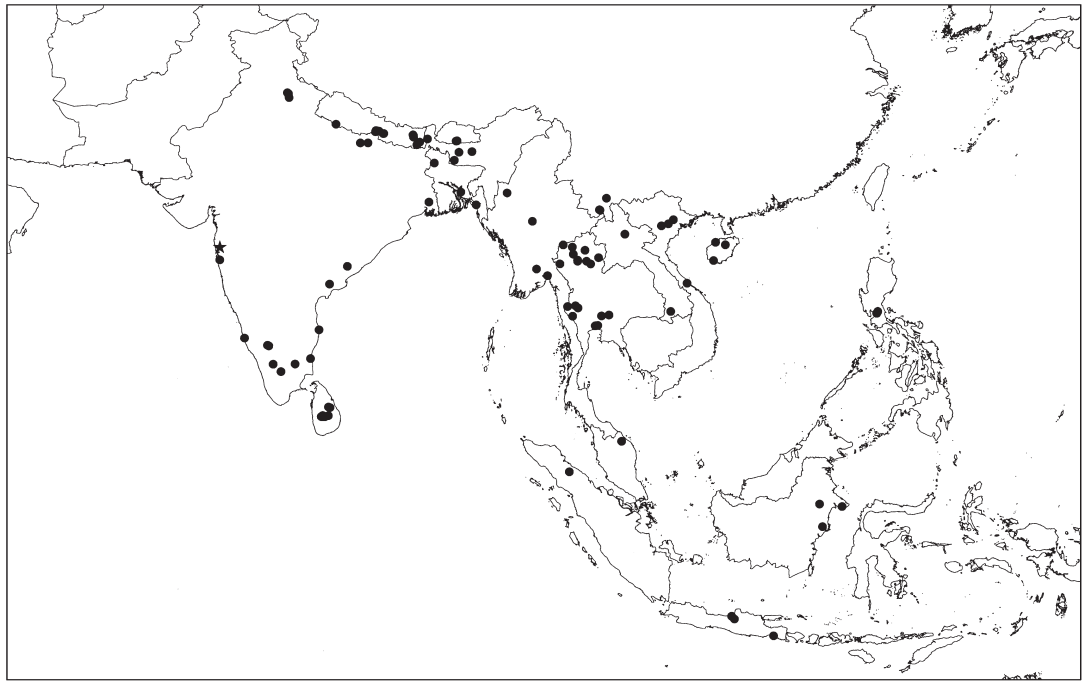

Map 3. Distribution of Mallotus nudiflorus (L.) Kulju \& Welzen (•) and M. polycarpus (Benth.) Kulju \& Welzen ( $\star$ ). 


\section{Mallotus pleiogynus Pax \& K. Hoffm. - Fig. 3; Map 4}

Mallotus pleiogynus Pax \& K. Hoffm. (1914) 187. - Octospermum pleiogynum (Pax \& K. Hoffm.) Airy Shaw (1965) 312; (1974) t. 3716; (1980) 176, t. 8. - Type: Hollrung 782 (holo B †; iso K), New Guinea, Kaiser-Wilhelmsland, Augusta Station.

Trees, up to $43 \mathrm{~m}$ high, dbh up to $70 \mathrm{~cm}$, dioecious, evergreen; buttresses absent to up to 2 by $1.2 \mathrm{~m}$; older branches more or less glabrescent, flowering branches $2-4 \mathrm{~mm}$ thick. Outer bark smooth, brown to grey; inner bark white to yellow within, cross section yellowish brown to brown. Indumentum dense in most parts, usually consisting of both short, (stellately) tufted and longer pilose, simple to (stellately) tufted hairs, whitish to brownish, sometimes one hair type rare or absent; glandular hairs present on some parts, yellowish to brownish to red. Stipules absent. Leaves alternate, subpeltate; petiole $3-13.5 \mathrm{~cm}$ long, usually with a basal constriction when dry, sparsely to densely hairy, often partly glabrescent; axillary buds often 2 above each other; blade ovate (to elliptic), $8.8-22.5$ by $7-16 \mathrm{~cm}$, length/width ratio $1.2-1.7$, papery, base rounded to obtuse (to acute), margin (sub)entire, apex acuminate to cuspidate; upper surface subglabrous (to sparsely hairy), glabrescent, usually granular dotted, basal extrafloral nectaries 2(-4), conspicuous, dark brown, raised, close together at the petiole insertion, marginal extrafloral nectaries 9-20 per side, smaller, on venation, $0.5-2 \mathrm{~mm}$ from the margin; lower surface densely hairy, glandular hairs present, yellowish (to \pm colourless), hair-tuft domatia sometimes present; venation triplinerved, nerves 5-8 per side, looped and closed near or at the margin. Inflorescences axillary racemes, single, or 2 together when staminate; bracts persistent to caducous, triangular, margin entire, apex acute to acuminate, hairy on both sides. Flowers: pedicels with a basal abscission zone; buds apiculate; sepals triangular to ovate, hairy outside. Staminate inflorescences up to 17 cm long, basally $1.1-1.8 \mathrm{~mm}$ thick; bracts $0.5-1.8$ by $0.2-0.4 \mathrm{~mm}$. Staminate flowers: buds globose; flowers $1.8-3.5 \mathrm{~mm}$ diam.; pedicel $0.5-2.6 \mathrm{~mm}$ long; sepals 3 or 4, $1-2.4$ by $0.7-2.1 \mathrm{~mm}$, usually unequal in width, apex acute to acuminate, glabrous inside; receptacle swollen into a torus; disc-glands absent; stamens $15-50$, filament $0.3-0.8$ $\mathrm{mm}$ long, free, glabrous, thecae $0.3-0.4$ by $0.2-0.3$ by $0.1-0.2 \mathrm{~mm}$, ellipsoid, opening latrorsely, connective papillose, darker coloured, conspicuously peltate, covering the thecae like an umbrella, thecae and connective usually with some yellowish glandular hairs; pistillode absent. Pistillate inflorescences up to $7.8 \mathrm{~cm}$ long, basally $1.5-2.4$ $\mathrm{mm}$ thick; flowers 4-8; bracts present on pedicel below abscission zone and often somewhat adnate to it, $1.2-2.4$ by $1.2-1.5 \mathrm{~mm}$, bracteoles sometimes present, near the abscission zone, smaller than the bracts. Pistillate flowers: buds ellipsoid, flowers 3.5-7 mm diam.; pedicel 2.4-6 mm long; sepals (4 or) 5 (or 6), 2.7-4.5 by 1.1-2.5 $\mathrm{mm}$, recurving and persistent in fruit, apex acute to acuminate, subglabrous (to sparsely hairy) inside; ovary (sub) glabrous, covered with glandular hairs, locules (7 or) 8 or 9 ; stigmas 2.2-4.7 mm long, sessile, \pm erect, slightly connate at base, narrowly triangular, plumose, outer surface with a \pm hairy groove with glandular hairs. Fruits indehiscent drupes, $2-4$ per infructescence, transversely ellipsoid, $9-12$ by $18-22 \mathrm{~mm}$, with 7-9 distinct longitudinal ridges when dry, surface somewhat irregulary wrinkled, covered with glandular hairs, yellow to orange when fresh, yellowish to reddish brown with dark grey ground colour when dry; pericarp toughly fleshy, hard when dry. Seeds radially arranged; obloid, somewhat flattened, $5.2-5.6$ by $6.2-6.8 \mathrm{~mm}$, surface slightly rugose, brown to light brown, shiny, sarcotesta absent. 


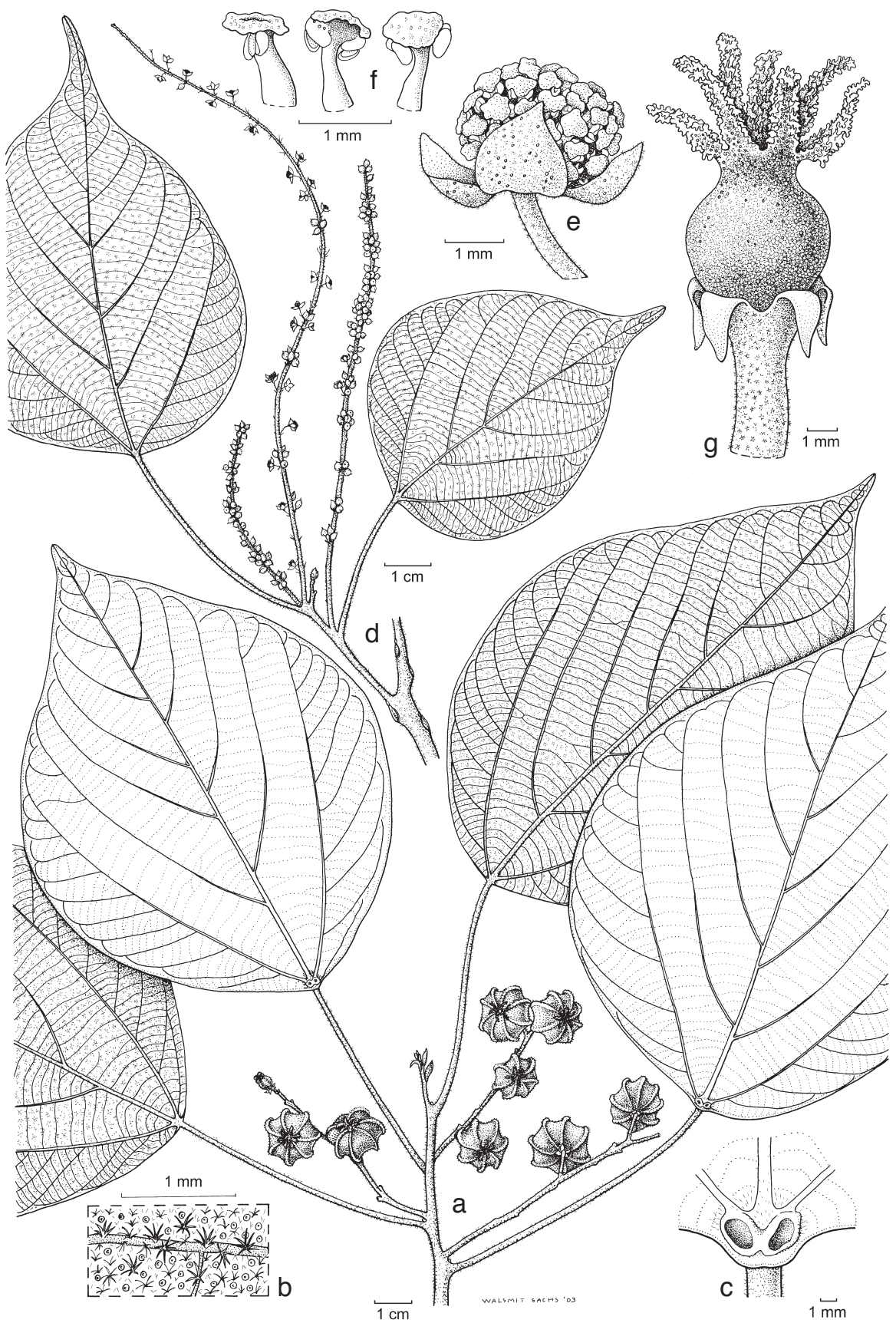

Fig. 3. Mallotus pleiogynus Pax \& K. Hoffm. a. Habit of pistillate plant with fruits; b. lower leaf surface with hairs and glandular hairs; c. extrafloral nectaries at the base of the upper leaf surface; d. staminate plant with inflorescence; e. staminate flower; f. stamens; g. pistillate flower $(\mathrm{a}-\mathrm{c}$ : Regalado \& Takeuchi 1495; d-f: BW 10061; g: BW 2709; all L). 


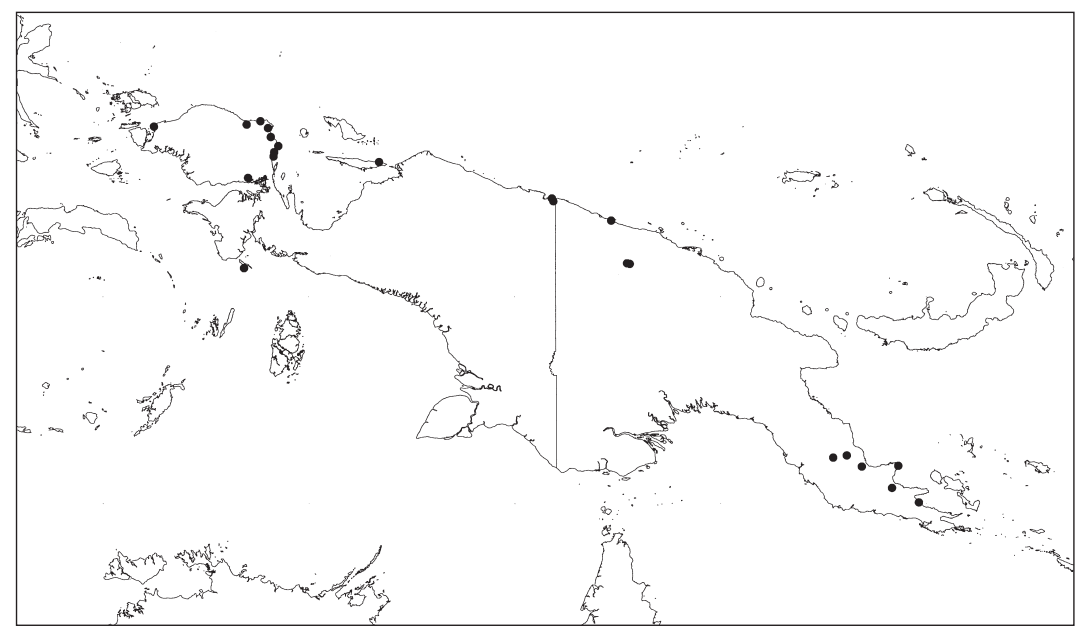

Map 4. Distribution of Mallotus pleiogynus Pax \& K. Hoffm.

Distribution - New Guinea.

Habitat \& Ecology - Locally rather common in primary or sometimes secondary forest; terrain usually flat; soil sandy to clayey, rarely loamy or limestone. Altitude up to $660 \mathrm{~m}$. Flowering and fruiting: throughout the year.

Vernacular names - Irian Jaya: Aromaraipi (Roberbai, Japen dialect); bangembo (Waskuk); manggafafin (Biak); naroe, sinaroe, tinaro (Mooi); sebijreraka, seborreraka (Manikiong); barorong, boear, m'brèrehie, njakwe, pembrièn. Papua New Guinea: Fofoto (Onjob, Koreaf dialect); osari (Orokaiva, Mumuni dialect); sikusikura (Managalase); hopkos mange.

\section{Mallotus polycarpus (Benth.) Kulju \& Welzen, comb. nov. - Fig. 4; Map 3}

Trewia polycarpa Benth. in Benth. \& Hook.f., Gen. Plant. 3, 1 (1880) 318, pro typo \& descr., excl. fig. ref. (see note 1); Hook.f. (1887) 423; Pax (1896) 53; Brandis (1906) 591; T. Cooke (1906) 614; Talbot (1911) 482; Gamble (1925) 1318. - Trewia nudiflora L. var. polycarpa (Benth.) Susila \& N.P. Balakr. (1998) 351, t. 2 (see note 2). - Lectotype (selected here): Law, Stocks et al. s.n. (holo K, barcode K000185021; iso GH, K, barcodes K000185022, K000185023), Concan.

Small trees up to $8 \mathrm{~m}$ high, dioecious, deciduous; branches ribbed when dry, (sub)glabrous (to sparsely hairy); flowering branches $2-4.5 \mathrm{~mm}$ thick. Indumentum with simple to (stellately) tufted hairs, short, whitish to yellowish; glandular hairs yellowish, sometimes absent. Stipules early caducous, only scars seen. Leaves opposite to subopposite, not peltate; petiole 3.5-7.4 cm long, often with a basal constriction when dry, subglabrous to sparsely hairy; blade ovate, $12.4-17.9$ by $7.3-14.5 \mathrm{~cm}$, length/width ratio 1-1.7, papery, base cordate to truncate, margin subentire, apex acuminate; upper surface glabrous to sparsely hairy at venation, usually granular dotted, extrafloral nectaries 2-11,(3-)7-50 mm from petiole insertion, at the base of the leaf, in an arch following the margin, sometimes up to middle part of the blade; lower surface sparsely hairy, glandular hairs absent to sparse, domatia absent; venation triplinerved (to 5-nerved), nerves 4 or 5 per side, looped and closed near the margin. Staminate inflorescences and 


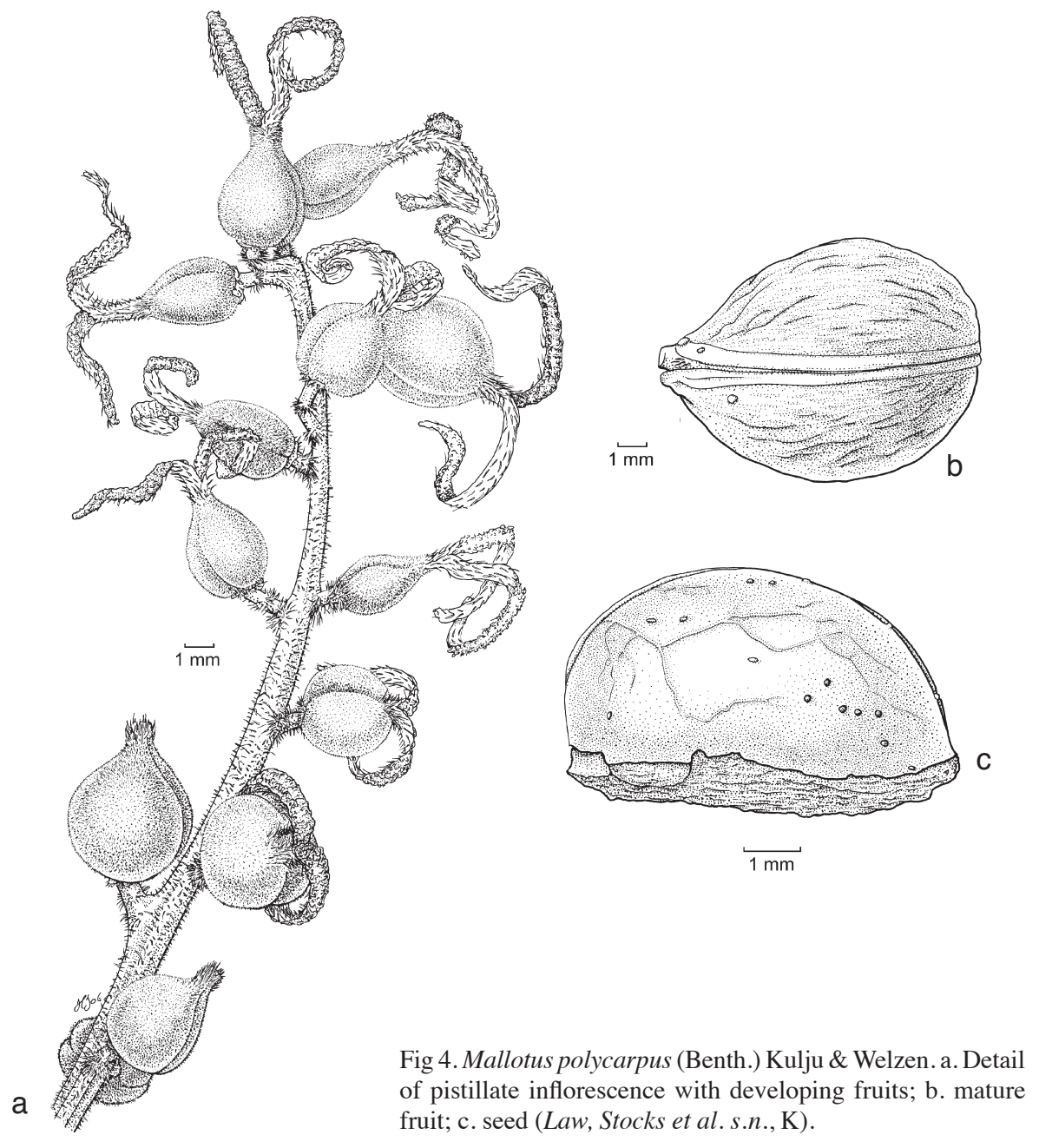

flowers unknown. Pistillate inflorescences axillary racemes, behind the leaves, single, $3-5.5 \mathrm{~cm}$ long, basally c. $1.5 \mathrm{~mm}$ thick, axis subglabrous to sparsely hairy; flowers $6-17$, also in basal part; bracts early caducous, not seen. Pistillate flowers: buds not seen; pedicel 3-6 $\mathrm{mm}$ long, subglabrous to sparsely hairy, with an abscission zone in basal or apical part; only remnants of calyx seen, connate, lobed, rupturing open?, early caducous, hairy outside, sparsely hairy inside; ovary ovoid, laterally flattened, with loculicidal grooves, densely hairy, glabrescent, locules 2; style 1-2 mm long, hairy; stigmas 8-14 mm long, papillose to somewhat plumose inside, hairy outside. Fruits dehiscent capsules, opening along loculicidal ridges, ovoid to ellipsoid, 12-14 by $10.5-13$ by $7.5-12 \mathrm{~mm}$, surface rugose, (sub) glabrous, brown; pericarp $0.25-1 \mathrm{~mm}$ thick, crustaceous. Seeds broadly ellipsoid with the side against the septum flattened, the two seeds of a fruit still attached to each other after dehiscence, $6.5-8$ by $6.5-7$ by $4.5-5 \mathrm{~mm}$, surface brown, \pm smooth, with sarcotesta. 
Distribution - India (Konkan).

Notes -1 . In the original description of Bentham (Bentham \& Hooker, 1880) no type specimen is cited for this species. Two illustrations of pistillate plants (Wight, 1852, t. 1871; Beddome, 1872, t. 281) are cited, but these are in serious conflict with the protologue and represent, in fact, $M$. nudiflorus (inflorescences with up to 5 flowers in apical part only, ovary 3- or 4-locular). A collection ('The Concan, Law, Stocks \&c.') is cited by Hooker (1887). These sheets match the original description well, and one of them has an annotation by Bentham. Therefore, this collection is here selected as the lectotype of Trewia polycarpa.

2. Susila Rani \& Balakrishnan (1998) erroneously cite the specimen "India Orientali, Wight 2629" (= Mallotus albus) as the type of T. polycarpa.

\section{DOUBTFUL SPECIES}

Trewia nudiflora L. var. dentata Susila \& N.P. Balakr. (1998) 352, t. 4. - Type: Santapau 15595 (holo CAL? n.v.), India, Maharashtra, Bombay, Khandala, Battery Hill Plateau $=\mathrm{cf}$. Mallotus repandus Müll.Arg.

\section{EXCLUDED SPECIES}

Trewia africana Baill. (1860) 68. - Type: Perrottet s.n.(G n.v.), Senegal, Casamancae $=$ Erythrococca africana (Baill.) Prain.

Trewia discolor Sm. (1819) 8; Müll.Arg. (1866) 954. - Type: Lamarck s.n. (LINN, J.E. Smith herb., microfiche seen, IDC \#5073, 930: 6), East Indies = Mallotus paniculatus (Lam.) Müll.Arg.

Trewia hernandifolia Roth (1821) 374; Müll.Arg. (1866) 954. - Type: Heyne s.n. $(\mathrm{B} \dagger)$, India orientalis = Macaranga spec.

Croton inophyllus G. Forst. (1786) 67. - Trewia inophylla (G. Forst.) Spreng. (1826) 906. - Lectotype (Green, 1986): Forster s.n. (holo K; iso BM, GOET), New Caledonia $=$ Baloghia inophylla (G. Forst.) P.S. Green.

Trewia macrophylla Blume (1826) 612 . - Trewia insignis Steud. (1841) 698. - Lectotype (Van Welzen, 1998): Blume '1521' (holo L, barcode L0026857; iso K), Indonesia, Java = Wetria insignis (Steud.) Airy Shaw.

Trewia pubescens Sm. (1819) 8; Müll.Arg. (1866) 954. - Type: Roxburgh s.n. (LINN, J.E. Smith herb., microfiche seen, IDC \#5073, 930: 5), Amboyna = Macaranga spec.

Trewia rusciflora Roth (1821) 374; Müll.Arg. (1866) 954. - Rottlera rusciflora (Roth) Spreng. (1826) 878. - Type: Heyne s.n. $(\mathrm{B} \dagger)$, India orientalis = Mallotus spec.

Trewia tricuspidata Willd. (1806) 835, nom. superfl. pro Mallotus cochinchinensis. - Type: Loureiro s.n.(BM), Cochinchina = Mallotus paniculatus (Lam.) Müll.Arg. (see Sierra \& Van Welzen, 2005). 


\section{ACKNOWLEDGEMENTS}

We would like to thank the following institutes for sending their material on loan or allowing us to examine the collections: A, BK, BKF, BM, BO, BR, BRI, CANB, CGE, CMU, E, G, GH, GOET, K, L, M, NSW, NY, PNH, QBG, TCD, US and W. Anita Walsmit Sachs and Hanneke Jelles made the beautiful drawings. Jan-Frits Veldkamp provided invaluable help with the nomenclature and Niels Raes assisted with the distribution maps. Pieter Baas, Stefano Draisma and Kenneth Wurdack (US) and an anonymous reviewer provided helpful comments on the manuscript. Gill Challen (K) and Petra Hoffmann (K) are thanked for the help with the Mallotus polycarpus type.

\section{REFERENCES}

Adanson, M. 1763. Familles des plantes 2. Vincent, Paris.

Airy Shaw, H.K. 1963. Notes on Malaysian and other Asiatic Euphorbiaceae. Kew Bull. 16: 341372.

Airy Shaw, H.K. 1965. Notes on Malaysian and other Asiatic Euphorbiaceae. Kew Bull. 19: 299328.

Airy Shaw, H.K. 1966. Malaysian and other Asiatic Euphorbiaceae. Kew Bull. 20: 379-415.

Airy Shaw, H.K. 1969. Malesian and other Asiatic Euphorbiaceae. Kew Bull. 23: 1-131.

Airy Shaw, H.K. 1972. The Euphorbiaceae of Siam. Kew Bull. 26: 191-363.

Airy Shaw, H.K. 1974. Noteworthy Euphorbiaceae from tropical Asia. Hooker's Icon. Pl. 38: 3716.

Airy Shaw, H.K. 1975. The Euphorbiaceae of Borneo. Kew Bull., Addit. Ser. 4.

Airy Shaw, H.K. 1980. The Euphorbiaceae of New Guinea. Kew Bull., Addit. Ser. 8.

Airy Shaw, H.K. 1981. The Euphorbiaceae of Sumatra. Kew Bull. 36: 239-374.

Airy Shaw, H.K. 1982. The Euphorbiaceae of Central Malesia (Celebes, Moluccas, Lesser Sunda Is.). Kew Bull. 37: 1-40.

Airy Shaw, H.K. 1983. An alphabetical enumeration of the Euphorbiaceae of the Philippine islands. Royal Botanic Gardens, Kew.

Backer, C.A. \& R.C. Bakhuizen van den Brink Jr. 1964. Flora of Java 1. Noordhoff, Groningen.

Baillon, H. 1858. Étude générale du groupe des Euphorbiacées. Masson, Paris.

Baillon, H. 1860. Species Euphorbiacearum. A. Euphorbiacées Africaines. Adansonia 1: 58-87.

Beddome, R.H. 1872. Flora sylvatica 2. Adelphi Press, Madras.

Bentham, G. \& J.D. Hooker. 1880. Genera plantarum 3, 1. Reeve \& Co, London.

Blume, C.L. 1826. Bijdragen tot de flora van Nederlandsch Indië. Lands Drukkerij, Batavia.

Bollendorff, S.M., P.C. van Welzen \& J.W.F. Slik. 2000. A taxonomic revision of Mallotus section Polyadenii (Euphorbiaceae). Blumea 45: 319-340.

Brandis, D. 1906. Indian trees. Constable \& Co., London.

Burman, N.L. 1768. Flora Indica. Haak \& Schreuder, Leiden \& Amsterdam.

Cooke, T. 1906. The flora of the presidency of Bombay 2, 3. Taylor \& Franchis, London.

Craib, W.G. 1911. Contributions to the Flora of Siam. Bull. Misc. Inform. Kew 1911: 385-474.

De Guzman, E.D., R.M. Umali \& E.D. Sotalbo. 1986. Guide to Philippine flora and fauna 3. JMC Press, Quezon City.

De Loureiro, J. 1790. Flora Cochinchinensis 1. De Loureiro, Ulyssipone.

Dinerstein, E. \& C.M. Wemmer. 1988. Fruits rhinoceros eat: Dispersal of Trewia nudiflora (Euphorbiaceae) in lowland Nepal. Ecology 69: 1768-1774.

Endlicher, S.L. 1843. Generum plantarum, Suppl. 3. Beck, Wien.

Esser, H.-J. 2003. Fruit characters in Malesian Euphorbiaceae. Telopea 10: 169-177.

Forster, G. 1786. Florulae insularum australium prodromus. Dieterich, Göttingen.

Gagnepain, F. \& L. Beille. 1925. Euphorbiaceae. In: M.H. Lecomte (ed.), Flore générale de l'IndoChine 5: 229-673. Masson \& Cie, Paris.

Gamble, J.S. 1925. Flora of the presidency of Madras 2, 7. West Newman \& Co. and Adlard \& Son, London.

Gardner, S., P. Sidisunthorn \& V. Anusarnsunthorn. 2000. A field guide to forest trees of Northern Thailand. Kobfai Publishing Project, Bangkok. 
Govaerts, R., D.G. Frodin \& A. Radcliffe-Smith. 2000. World checklist and bibliography of Euphorbiaceae 3 \& 4 . Royal Botanic Gardens, Kew.

Green, P.S. 1986. New combinations in Baloghia and Codiaeum (Euphorbiaceae). Kew Bull. 41: 1026.

Grierson, A.J.C. \& D.G. Long. 1987. Flora of Bhutan 1, 3. Royal Botanic Garden, Edinburgh.

Haegens, R.M.A.P. 2000. Taxonomy, phylogeny, and biogeography of Baccaurea, Distichirhops, and Nothobaccaurea (Euphorbiaceae). Blumea Suppl. 12.

Hooker, J.D. 1887. Flora of British India 5. Reeve \& Co., London.

Kiu, H.S., S.M. Hwang \& Y.T. Chang. 1996. Euphorbiaceae 2. Flora Reipublicae Popularis Sinicae 44, 2. Science Press, Beijing.

Klotzsch F. \& A. Garcke. 1862. Die Botanischen Ergebnisse der Reise seiner Königl. Hoheit des Prinzen Waldemar von Preussen. Decker, Berlin.

Kulju, K.K.M., S.E.C. Sierra, S.G.A. Draisma, R. Samuel \& P.C. van Welzen. In press. Molecular phylogeny of Macaranga, Mallotus, and related genera (Euphorbiaceae s.s.): insights from plastid and nuclear DNA sequence data. Amer. J. Bot.

Kulju, K.K.M. \& P.C. van Welzen. Proposal to conserve the name Mallotus against Trewia (Euphorbiaceae s.s.). Submitted to Taxon.

Kurz, S. 1877. Forest Flora of British Burma 2. Goverment printing, Calcutta.

Linnaeus, C. 1753. Species plantarum 2. Laurentii Salvii, Stockholm.

McNeill, J., F.R. Barrie, H.M. Burdet, V. Demoulin, D.L. Hawksworth, K. Marhold, D.H. Nicolson, J. Prado, P.C. Silva, J.E. Skog, J.H. Wiersema \& N.J. Turland (eds.). 2006. International Code of Botanical Nomenclature (Vienna Code) adopted by the Seventeenth International Botanical Congress Vienna, Austria, July 2005. Regnum Veg. 146.

McPherson, G. 1995. On Mallotus and Deuteromallotus (Euphorbiaceae) in Madagascar. Bull. Mus. Natl. Hist. Nat., Paris 17: 169-173.

Merrill, E.D. 1906. The flora of the Lamao Forest Reserve. Philipp. J. Sci. 1, Suppl. 1: 1-141.

Merrill, E.D. 1912. Notes on Philippine Euphorbiaceae. Philipp. J. Sci., Bot. 7: 379-410.

Merrill, E.D. 1923. An enumeration of Philippine flowering plants 2. Bureau of Printing, Manila.

Miquel, F.A.W. 1859. Flora van Nederlandsch Indië 1, 2. Fleischer, Leipzig.

Müller Argoviensis, J. 1865. Euphorbiaceae. Linnaea 34: 1-224.

Müller Argoviensis, J. 1866. Euphorbiaceae. In: A. de Candolle (ed.), Prodromus systematis universalis regni vegetabilis 15, 2: 189-1260. Masson \& Filii, Paris.

Necker, N.J. 1790. Elementa botanica 2. Neowedae, Rhenum.

Nicolson, D.H., C.R. Suresh \& K.S. Manilal. 1988. An interpretation of Van Rheede's Hortus Malabaricus. Regnum Veg. 119.

Pax, F. 1896. Euphorbiaceae. In: A. Engler \& K. Prantl (eds.), Die natürlichen Pflanzenfamilien 3, 5: 1-119. Engelmann, Leipzig.

Pax, F. \& K. Hoffmann. 1914. Euphorbiaceae-Acalypheae-Mercurialinae. In: A. Engler (ed.), Das Pflanzenreich IV.147.vii. Engelmann, Leipzig \& Berlin.

Pax, F. \& K. Hoffmann. 1931. Euphorbiaceae. In: A. Engler \& H. Harms (eds.), Die natürlichen Pflanzenfamilien ed. 2, 19C: 11-233. Engelmann, Leipzig.

Philcox, D. 1997. Euphorbiaceae. In: M.D. Dassanayake (ed.), A revised handbook to the flora of Ceylon. Balkema, Rotterdam.

Radcliffe-Smith, A. 2001. Genera Euphorbiacearum. Royal Botanic Gardens, Kew.

Roth, A.G. 1821. Novae plantarum species praesertim Indiae Orientalis. Vogleri, Halberstadii.

Sierra, S.E.C., M. Aparicio, M.J.H. Gebraad, K.K.M. Kulju \& P.C. van Welzen. 2007. The morphological range in Mallotus (Euphorbiaceae) and a taxonomic revision of its section Rottleropsis (including Axenfeldia) in Malesia, Thailand and Africa. Blumea 52: 21-113.

Sierra, S.E.C., M. Aparicio, K.K.M. Kulju, Ž. Fišer, P.C. van Welzen \& R.W.J.M. van der Ham. 2006. Re-shaping Mallotus [part 1]: expanded circumscription and revision of the genus Cordemoya (Euphorbiaceae). Blumea 51: 519-540.

Sierra, S.E.C. \& P.C. van Welzen. 2005. A taxonomic revision of Mallotus section Mallotus (Euphorbiaceae) in Malesia. Blumea 50: 249-274.

Sierra, S.E.C., P.C. van Welzen \& J.W.F. Slik. 2005. A taxonomic revision of Mallotus sections Philippinenses (former section Rottlera - Euphorbiaceae) in Malesia and Thailand. Blumea 50: 221-248. 
Slik, J.W.F. 2005. Assessing tropical lowland forest disturbance using plant morphological and ecological attributes. Forest Ecol. Manag. 205: 241-250.

Slik, J.W.F., P.J.A. Keßler \& P.C. van Welzen. 2003. Macaranga and Mallotus species (Euphorbiaceae) as indicators for disturbance in the mixed lowland dipterocarp forest of East Kalimantan (Indonesia). Ecol. Indic. 2: 311-342.

Slik, J.W.F. \& P.C. van Welzen. 2001a. A phylogeny of Mallotus (Euphorbiaceae) based on morphology: Indications for a pioneer origin of Macaranga. Syst. Bot. 26: 786-796.

Slik, J.W.F. \& P.C. van Welzen. 2001b. A taxonomic revision of Mallotus sections Hancea and Stylanthus (Euphorbiaceae). Blumea 46: 3-66.

Smith, J.E. 1819. Trewia. In: A. Rees (ed.), The cyclopaedia; or universal dictionary of arts, sciences and literature 36. Longman et al., London.

Smith, J.J. 1910. Euphorbiaceae. Bijdrage tot de kennis der boomsoorten op Java. Meded. Dept. Landb. Ned.-Indië 10: 9-637.

Sprengel, C. 1826. Systema vegatabilium 3. Dieterich, Göttingen.

Steudel, E.T. 1841. Nomenclator botanicus 2, 2. Cottae, Stuttgart \& Tübingen.

Stokes, J. 1812. A botanical materia medica 4. Johnson \& Co., London.

Susila Rani, S.R.M. \& N.P. Balakrishnan. 1998. Notes on Trewia nudiflora L. (Euphorbiaceae) and its varieties. J. Econ. Taxon. Bot. 22: 345-352.

Swart, J.J. 1942. A monograph of the genus Protium and some allied genera (Burseraceae). Recueil Trav. Bot. Néerl. 39: 211-446.

Talbot, W.A. 1911. Forest flora of the Bombay presidency and Sind 2. Government Photozincographic Department, Poona.

Troup, R.S. 1921. The silviculture of Indian trees 3. Clarendon Press, Oxford.

Van Rheede, H. 1678. Hortus Indicus Malabaricus 1. Van Someren \& Van Dyck, Amsterdam.

Van Welzen, P.C. 1998. Revisions and phylogenies of Malesian Euphorbiaceae: Subtribe Lasiococcinae (Homonoia, Lasiococca, Spathiostemon) and Clonostylis, Ricinus, and Wetria. Blumea 43: 131-164.

Vidal y Soler, S. 1886. Revision de plantas vasculares Filipinas. Perez, Manila.

Vu Van Dung (ed.). 1996. Vietnam forest trees. Agricultural Publishing House, Hanoi.

Watt, G. 1893. A dictionary of the economic products of India 6, 4. Allen \& Co., London.

Webster, G.L. 1994. Synopsis of the genera and suprageneric taxa of Euphorbiaceae. Ann. Missouri Bot. Gard. 81: 33-144.

Whitmore, T.C. 1973. Tree Flora of Malaya 2. Longman, London.

Wight, R. 1852. Icones plantarum Indiae Orientalis. Pharoah, Madras.

Willdenow, C.D. 1797. Schradera et Rottlera, bina nova plantarum genera. Gött. J. Natürwiss. 1: 1-9. Willdenow, C.D. 1806. Species Plantarum ed. 4, 2. Nauk, Berlin.

Wurdack, K.J., P. Hoffmann \& M.W. Chase. 2005. Molecular phylogenetic analysis of uniovulate Euphorbiaceae (Euphorbiaceae sensu stricto) using plastid rbcL and trnL-F DNA sequences. Amer. J. Bot. 92: 1397-1420.

\section{IDENTIFICATION LIST}

The numbers behind the collector numbers refer to the following taxa:

$1=$ M. cumingii Müll.Arg.

$2=$ M. nudiflorus (L.) Kulju \& Welzen

$3=$ M. pleiogynus Pax \& K. Hoffm.

$4=$ M.polycarpus (Benth.) Kulju \& Welzen

Adduru 266: 1 - Afriastini 2030: 1 - Ahern's collector 545: 1.

Baku 2086: 1 - Balansa 3309: 2; 3321: 2 - Balapure \& Pandry 72458: 2 - bb series 14211: 1; 14213: 1; 14677: 2; 29254: 2; 32646: 3; 33257: 3; 33329: 3 - Bogor Botanical Garden III.D.7: 2; IX.A.103: 2; IX.A.118: 2; IX.A.123: 2; IX.A.132: 2; XI.B.XVI.58: 1; XV.J.BXX.1: 2 - Bor 11290: 2 - BS series 3311: 1; 4575: 1; 8014: 1; 9309: 1; 13317: 1; 15763: 1; 29022: 1; 29069: 1; 29344: 1; 33083: 1; 39513: 1; 40942: 1; 75650: 1; 76314: 1; 76344: 1; 80605: 1; 80686: 1 ; 80720: 1 - BSI series (Botanical Survey of India) 167437: 4 - Burley et al. 3587: 1; 3822: 
1; 3879: 1; 3893: 1 - BW series 307: 3; 2634: 3; 2709: 3; 2737: 3; 4364: 3; 5792: 3; 5926: 3; 10061: 3 ; 10124: 3 ; 11699: 3 ; 11915: 3 ; 12446: $3 ; 12498: 3$.

Carr 16400: 3 - Chand 3008: 2; 3133: 2; 7686: 2 - Clarke 4292: 2 - M.S. Clemens 1024: 1 W. Condon \& A. Condon 28: 2 - Coode 6270: 1 - Cuming 798: 1; 1267: 2.

De Vogel 5080: 1; 5498: 1 — Dickason 6831: 2; 6921: 2; 7034: 2; 7187: 2; 7197: 2.

Ebalo 612: 1; 640: 1; 816: 1 - Edgeworth 159: 2 - Elmer 7534: 1; 8295: 1;9102: 1;9123: 1; 9205: 1; 9489: 1 ; 9928: 1 ; 10143: 1 ; 11086: 1 ; 11155: 1 ; 13963: 1; 15628: 1; 15673: 1; 17228: $1 ; 17471$ : 1; 17641: 1; 17643: 1; 17784: 1 - Endert 1992: 2; 2444: 2.

FB series 623: 1; 1251: 1; 2798: 1; 2977: 1; 3180: 1; 3274: 1; 11990: 1; 15391: 1; 18564: 1; 19777: 1; 19809: 1; 21038: 1; 25580: 1; 31118: 1 - Fernandes 31: 2 - Forbes 2704: 2.

Gamble 2462: 2; 2795A: 2; 9627: 2; 21770: 2 - Gaudichaud 272: 2 - Geesink \& Maxwell 7811: 2 - Geesink et al. 5933: 2; 5952: 2 - Ghosh 90: 2 - Ghoudhury 98: 2; 166: 2 - Grierson \& Long 1477: $2 ; 3646: 2$.

Haines 5828: 2 - Harsukh 22522B: 2 - Hatusima \& Sato 28648: 1 - Henry 11776B: 2; 13010: 2 - Hollrung 782: 3 - Holman 31: 1 - Hoogland 4522: 3 - Hoogland \& Craven 10348: 3 — Hoogland \& MacDonald 3494: 3 - How 70878: 2; 71718: 2 - How \& Chun 70022: 2 - Huq \& Mia 10501: 2 .

Johansson et al. 89: 1; 192: 1; 286: 1.

Kerr 967: 2; 4705: 2; 14354: 2 - King's collector 302: 2 - Koorders 2710: 2; 2711: 2; 2721: 2; 2722: 2 ; 2723: 2; 2724: 2; 2747: 2; 2748: 2; 9857: 2; 9861: 2; 10097: 2; 12886: 2; 13731: 2; 16929: $1 ; 16933$ : $1 ; 16964: 1 ; 16967: 1 ; 16968: 1 ; 16971: 1 ; 16972: 1 ; 25077: 2 ; 25180: 2 ; 25428$ : 2; 25496: 2 - Kostermans (Khwae Noi River Basin Expedition) 251: 2; 6929: 2; 6984: 2; 6986: 2; 6989: 2; 9928: 2 .

Lace 2916: 2 - Lakshnakara 319: 2 - Lau 365: 2; 1099: 2; 1571: 2; 2956: 2; 3172: 2; 25401: 2; 26118: 2 - Lei 434: 2; 590: 2 - Liang 66243: 2 - Loher 48: 1; 4638: 1; 4812: 1 ; 4813: 1 ; 4840: 2; 4900: 1; 6879: 1; 13014: 1; 13627: 1; 14108: 1; 14278: 1; 14550: 1 - Lörzing 5766: 2.

Madulid 6798: 1 - Madulid \& Majaducon 8342: 1 - Marcan 574: 2; 684: 2; 1631: 2 - Maxwell 88-307: 2; 89-271: 2; 89-559: 2; 89-589: 2; 89-796: 2; 91-1011: 2; 93-461: 2; 94-29: 2; 94-849: 2; 95-7: 2; 95-9: 2; 95-107: 2; 96-956: 2; 97-116: 2; 97-757: 2; 98-505: 2; 00-39: 2 - McClure CCC 8884: 2; CCC 9145: 2 - McGregor BC 32370: 1 - Merrill 2271: 1 - Minaki et al. 9040054: 2 - Mooney 686: 2 - Musser 6: 1; 441: 1 .

Nautiyal 46: 2 - NGF series 526: 3; 28607: 3; 46918: 3 - Nimanong \& Phusomsaeng 1826: 2 - Noshiro et al. 9840212: 2.

Pételot 6389: 2; 6508: 2 - Pierre 417: 2 - PNH series 2904: 1; 3418: 1; 3555: 1; 6065: 1; 6075: 1; 6897: 1 ; 15503: 1 ; 17474: 1 ; 17610: 1 ; 22901: $1 ; 33444: 1 ; 36110: 1 ; 37309$ : $1 ; 37527$ : 1 ; 80558: 1 - Poilane 1046: 2 - PPI series 2128: 1; 2250: 1; 6317: 1; 7183: 1; 7195: 1; 7569: 1; 8090: 1 ; 8779: 1; 9959: 1; 12293: 1; 15462: 1; 17248: 1; 17257: 1; 17973: 1; 18043: 1; 20181: 1; 22097: 1; 22267: 1; 26298: 1 - Prawiroatmodjo \& Maskuri 1280: 1 - Prazer 6: 2 - Pullen 5636: 3; 5681: $3 ; 5816: 3$.

Ramos 1025: 1; 1845: 1 - Regalado \& Takeuchi 1495: 3 - RHT series 1425: 2; 1815: 2; 23683: 2; 52604: 2 .

S series 28705: 1 - Saldanha 13163: 2; 13292: 2; 16226: 2 - Saldanha \& Ramamoorthy HFP 1699: 2 - Samnasema 115: 2 - Santos 5335: 1 - SF series 10169: 2 - Shnestha 3922: 2 - SMHI series 1551: 1 - Smith 5347: 2 - Soejarto et al. 5859: 2; 7786: 1; 7797: 1 - Sørensen et al. 7016: 2 - Stainton 5231: 2; 5233: 2; 5268: 2; 6110: 2; 6239: 2 - Suzuki et al. 8820143: 2.

Takeuchi \& Regalado 10287: 3 - Teijsmann HB 12429: 1 - Thorel 2238: 2 - Thwaites CP 2930: 2 - Troth 703: 2 - Tsang 364: 2; 505: 2 .

Vaid 23466: 2 - Van Balgooy 3055: 1; 3427: 1 - Van Beusekom \& Santisuk 2941: 2 - Vanpruk 123: 2 —Vidal 129: 2 ; 557: $1 ; 1002: 2 ; 3721: 1 ; 3750: 1 ; 3754: 1 ; 3758: 1 ; 3763: 1 ; 3889: 1 ; 3890: 1$.

Wallich 7816B: 2; 7817B: 2; 7837: 2 - Wang 32787: 2; 36372: 2; 36718: 2; 75632: 2; 75633: 2; 76388: $2 ; 77874: 2 ; 78038: 2 ; 80953: 2$ - Wenzel 71: $1 ; 208: 1 ; 211: 1 ; 1316: 1 ; 1337: 1 ; 1522: 1$; 1601: 1; 2711: 1;2870: 1; 2914: 1 - Wesche 1181: 2 - Whitmore 3524: 1 — Wight KD 2626: 2; KD 2627: 2 - Williams 262: 2 - Williams \& Stainton 8275: 2; 8542: 2; 8549: 2 - Worthington 893: 2; 1338: 2; 1549: 2; 4525: 2; 5338: 2; 6286: 2.

Zwickey 713: 1 . 